thế không ảnh hưởng đến tiến trình cuộc chuyển dạ. Khi dây rốn ngắn, $\mathrm{DRQC}$ có thể khiển thai nhi khó lọt, ảnh hưởng tới độ mở cổ tử cung do đầu thai nhi cúi không tốt. Tuy nhiên $\mathrm{DRQC}$ kèm dây rốn ngắn là rất ít. Nhiều nghiên cứu cho thấy chỉ khi dây rốn quấn cổ chặt hoặc quấn nhiều vòng mới có thể khiến thai nhi bị thiếu oxy gây suy thai trong chuyển dạ với hai biểu hiện đặc trưng trên lâm sàng là nước ối nhuộm phân su và nhịp tim thai bất thường.

Tóm lai, với DRQC một vòng rất ít khi gây ra vấn đề bất lợi cho cả me và thai nhi. Thai nhi bị DRQC một vòng có thế được sinh dễ dàng qua ngã âm đạo và an toàn. Giới hạn ở nghiên cứu này là chúng tôi chưa ghi nhận được số trường hợ DRQC một vòng chăt để so sánh với nhóm dây rốn quấn cổ một vòng lỏng cũng như chưa đánh giá được một yếu tố nguy cơ khá quan trọng trong chuyển dạ đó là chuyển dạ đình trệ do ngôi cúi kém. Ngoài ra mẫu nghiên cứu còn nhỏ và chỉ thực hiện ở một trung tâm nên chưa thể suy rộng cho mẫu dân số. Cần thiết có những nghiên cứu tiền cứu, mẫu lớn và đa trung tâm đề khẳng định kết quả này.

\section{KẾT LUẬN}

Chưa tìm thấy mối liên quan giữa dây rốn quấn cổ một vòng với các yếu tố nguy cơ trong chuyển dạ như ổi nhuộm phân su, biểu đồ tim thai bất thường, sử dụng oxytocin để tăng và cũng cũng chưa tìm thấy mối liên quan giữa dây rốn quấn cổ một vòng với kết thúc thai kỳ bất lợi vì vậy can thiệp sinh là không cần thiết ở thai nhi có dây rốn quấn cổ.

\section{TÀI LIẸU THAM KHẢO}

1 Shrestha NS, Singh N. (2007) Nuchal cord and perinatal outcome. Kathmandu Univ Med J (KUMJ). Jul-Sep;5(3):360-3

2. Hayes DJL, Warland J, Parast MM, et al. (2020) Umbilical cord characteristics and their association with adverse pregnancy outcomes: A systematic review and meta-analysis. PLoS One. Sep 24;15(9):e0239630.

3. Sherer DM, Sokolovski M, Dalloul M, KhouryCollado F, Abulafia 0. (2005) Is fetal cerebral vascular resistance affected by the presence of nuchal cord(s) in the third trimester of pregnancy? Ultrasound Obstet Gynecol. May;25(5):454-8.

4. Kong CW, Chan LW, To WW. (2015) Neonatal outcome and mode of delivery in the presence of nuchal cord loops: implications on patient counselling and the mode of delivery. Arch Gynecol Obstet. Aug;292(2):283-9.

5. Bernad ES, Craina M, Tudor A, Bernad SI. (2012) Perinatal outcome associated with nuchal umbilical cord. Clin Exp Obstet Gynecol.;39(4):494-7.

6. Trân Quang Hiền và Nguyêen Ngọc Thoa (2008) "Tỳ lệ dây rốn quấn cổ thai nhi trong chuyển dạ và các yếu tố liên quan". http://hosrem.org.vn/detailNews/thongtin/186

7. Peregrine E, P O'Brian, Jauniaux E.(2005) neck cord Ultrasound detected before induction of labor and cesarean risk. Obstet Gynecol Ultrasound; 25: 160-4.

8. Sheiner E, Abramowicz JS, Levy A, Silberstein T, Mazor M, Hershkovitz R. (2006) Nuchal cord is not associated with adverse perinatal outcome. Arch Gynecol Obstet. May; 274(2):81-3.

\title{
TỶ LÊ VÀ MộT SỐ YẾU TỐ LIÊN QUAN ĐẾN HUYẾT THANH DƯƠNG TÍNH VỚI TOXOPLASMA GONDII Ở PHU NỮ TUỔI SINH ĐẺ HUYỆN KRÔNG BÔNG TỈNH ĐẮK LẮK NĂM 2020
}

\section{Trần Vũ Hoà ${ }^{1}$, Thân Trọng Quang ${ }^{2}$} Lê Minh Hoài An ${ }^{1}$, Nguyễn Trần Uyên Phương ${ }^{1}$

\section{TÓM TẮT}

Mục tiêu: Bệnh Toxoplasmosis là một vấn đề sức khỏe cộng đồng trên toàn thế giới. Bệnh do ký sinh trùng Toxoplasma gondii (T. gondii) gây ra, là một lọại ký sinh trùng nội bào bắt buộc, có khả năng lây nhiếm nhiều động vật máu nóng bao gồm cả con người, dẫn

\footnotetext{
${ }^{1}$ Bệnh viện Từ Dũ

Đại học Tây Nguyên

Chịu trách nhiệm chính: Nguyễn Trân Uyên Phương

Email: ntuphuong.iu@gmail.com

Ngày nhận bài: 19.11.2020

Ngày phản biện khoa học: 23.12.2020

Ngày duyệt bài: 7.01.2021
}

đến một bệnh phổ biến trên toàn câu, làm ảnh hưởng đến sức khỏe cộng đồng. Xu thế hiện nay đẩy mạnh việc chăm lo cho sức khỏe trong cộng đồng, bệnh do Toxoplasma đang được nhiều nhà̀ nghiên cứu trên toàn thế giới quan tâm từ nhiều khía cạnh khác nhau. Việc nâng cao nhận thức về bệnh $T$. gơndii là rất cần thiết cho phòng ngừa tình trạng lây nhiễm trong cộng đồng, đặc biệt là những phụ nữ trong độ tuổi sinh đẻ, có thể han chế những yếu tố nguy cơ có thể ảnh hưởng đển thời kỳ mang thai. Tại Việt Nam, các nghiên cứu về nhiễm T. gondii trong cộng đồng chưa nhiều, đặc biệt khu vực miền Trung và Tây Nguyên cho đến nay rất ít đề tài nghiên cứu nhiễm $T$. gondii. Để xác định tỷ lệ huyết thanh dương tính $T$. gondii cũng như một số yếu tố liên quan góp phần vào sự lưu hành của bệnh và đề xuất biện pháp phòng 
chống, chúng tôi thực hiện đề tài: "Tỷ lệ và một số yếu tố liên quan đến huyết thanh dướng tính với Toxoplasma gondii ở phụ nữ tuổi sinh đẻ huyện Krông Bông, tỉnh Đắk Lắk năm 2020". Phương pháp: Nghiên cứu được thực hiện tại Xã Yang Reh, Xã Ea Trul và Xã Hòa S̛ơn, Huyện Krông Bông, Tỉnh Đắk Lắk. Thời gian nghiên cứu từ tháng 01 năm 2020 đến tháng 07 năm 2020. Đối tượng nghiên cứu: 396 Phụ nữ trong độ tuổi sinh đẻ từ 16-49 tuổi đang sinh sống trên địa bàn nghiên cứu của huyện Krông Bông, Tỉnh Đắk Lắk. Phương pháp nghiên cứu: Sử dụng thiết kế nghiên cứu cắt ngang mô tả. Một mẫu máu $4 \mathrm{ml}$ được thu thập từ mỗi người tham gia và các mẫu huyết thanh được kiểm tra sự hiện diện của các kháng thể IgG đặc hiệu của T.gondii bằng bằng xét nghiệm huyết thanh chẩn đoán ELISA. Tất cả số liệu được phân tích bằng phần mềm Epidata 3.1, STATA 10.0. Kết quả: Trong tổng số 396 mẫu máu của đối tượng nghiên cứu có 53 mâu có huyết thanh dương tính với T. gondii IgG, chiếm tỷ lệ 13,4\%. Trong đó đối tượng tham gia nghiên cứu tại Xã Hòa Sơn tỷ lệ huyết thanh dương tính chiếm 4,3\%, Xã Yang Reh 29,2\% và Xã Ea Trul 19,2\%. Kết quá điểu tra nghiên cứu cho thấy tỷ lê nhiễm khá cao trong cộng đồng, đặc biệt là phự nữ trong đô tuổi sinh đẻ tai điểm nghiển cứu. Đồng thời cho thấy tỷ lệ nhiễm T. gondii có mối liên liên đến nuôi mèo, tiếp xúc mèo, sử dụng nguồn nước không đảm bảo vệ sinh, nghề nghiệp buôn bán... Kết luận: Nguy cơ về nuôi mèo, tiếp xúc mèo, tình trạng vệ sinh ăn uống, tình trạng nghề nghiệp, được xem là các yếu tố nguy cớ lây nhiễm T.gondii.

\section{SUMMARY \\ THE POSITIVE RATE OF TOXOPLASMA GONDII FROM SERUM AND RELATED FACTORS OF WOMEN AT REPRODUCTIVE AGE IN KRONG BONG, DAK LAK PROVINCE IN 2020}

Objectives: Toxoplasmosis is a public health problem around the world. The disease caused by the parasite Toxoplasma gondii (T. gondii), an obligatory intracellular parasite and capable of infecting many warm-blooded animals including humans leads to a widespread disease worldwide and affects public health. The current trend promotes health care in the community and diseases caused by Toxoplasma is concerned by many researchers around the world by many different perspectives. Raising awareness about T. gondii disease is essential to prevent infections in communities, especially women at childbearing age who can limit the risk factors affecting to pregnancy period. In Vietnam, there are not many studies on $\mathrm{T}$. gondii infection in the community, especially in the Central region and the Central Highlands. To determine the $T$. gondii positive rate in serum as well as a number of related factors contributing to the prevalence of the disease and propose preventive ways, we carried out the topic: "The positive rate of Toxoplasma gondii from serum and related factors of women at reproductive age in Krong Bong, Dak Lak province in 2020". Methods: The study was conducted in Yang Reh, Ea Trul and Hoa Son areas belonged to Krong Bong, Dak Lak Province. Research was from January 2020 to July 2020. There were 396 women aged 16-49 years old in Krong Bong, Dak Lak province. Research method was using descriptive cross-sectional design. A $4 \mathrm{ml}$ blood sample was collected from each participant and serum samples were tested for the presence of T.gondii-specific IgG antibodies by ELISA diagnostic serum assay. All data were analyzed by using Epidata 3.1, STATA 10.0 software. Results: In a total of 396 blood samples in this study, there were 53 samples with the positive results for T. gondii IgG, accounting for $13,4 \%$. For participants in Hoa Son, Yang Reh and Ea Trul, the percentage of positive result were $4,3 \% \%, 29,2 \%$ and $19,2 \%$, respectively. The analyzed data showed that the infection rate was quite high in the community, especially women of reproductive age. Furthermore, the prevalence of $\mathrm{T}$. gondii infection was related to raising cats, contacting cats, using unhygienic water, trade... Conclusion: Risks for feeding cat, contacting cats, sanitary conditions and occupational conditions were considered as risk factors for T.gondii infection.

\section{I. ĐẶT VẤN ĐỀ}

Bệnh Toxoplasmosis là một vấn đề sức khỏe cộng đồng trên toàn thế giới. Bệnh do ký sinh trùng Toxoplasma gondii ( $T$. gondii) gây ra, là một loaai ký sinh trùng nội bào bắt buộc, có khả năng lẩy nhiễm nhiều động vật máu nóng bao gồm cả con người, dẫn đến một bệnh phổ biến trên toàn cầu, làm ảnh hưởng đến sức khỏe cộng đồng và Toxoplasmosis là một căn bệnh ảnh hưởng đến 500 triệu người trên toàn thế giới [4]. Bệnh lây truyền qua thực phẩm đứng hàng thứ ba trên thế giới sau Listeria sp. và Samonella sp., đặc biệt hay gặp ở những nước có thói quen ăn thịt sống và nuôi mèo nhiều trong gia đình [5]. Nhiễm trùng có thể dẫn đến thai chết lưu, sây thai hoặc các khuyết tật bẩm sinh khi mang thai, cũng như viêm não ở những bệnh nhân HIV/AIDS [3], [4].

Người bị nhiếm T.gondii qua đường tiêu hóa bằng 2 cách: ăn phải thịt gia súc có chứa nang ký sinh trùng chưa được nấu kỹ hoặc khi ăn, uống phải thức ăn, nước uống bị nhiếm nang trứng. Cũng có thể xảy ra lây truyền dọc từ me bị nhiễm sang thai nhi. Các nghiên cứu dịch tễ cho thấy bệnh có mặt ở khắp nơi trên thế giới, kể cả các nước phát triển [4].

Quá trình nhiễm T.gondii có thể bị ảnh hưởng bởi các điều kiện khác nhau, như các nguồn và mức độ tiếp xúc với ký sinh trùng. Hoặc giữa các quốc gia và khu vực, bị ảnh hưởng bởi các yếu tố khác như khí hậu, tình trang vệ sinh và chế độ ăn uống của cá nhân. Yểu tố nguy cơ khác nhiễm T. gondii, bao gồm tuổi, giới tính, quan hệ gần gũi với mèo, dọn phân mèo và trình độ văn hóa thấp.

Xu thế hiện nay đẩy mạnh việc chăm lo cho sức khỏe trong cộng đồng, bệnh do Toxoplasma 
đang được nhiều nhà nghiên cứu trên toàn thế giới quan tâm từ nhiều khía cạnh khác nhau [3]. Việc nâng cao nhận thức về bệnh $\mathrm{T}$. gondii là rất cần thiết cho phò̀ng ngừa tình trang lây nhiếm trong cộng đồng, đặc biệt là những phụ nữ trong độ tuổi sinh đẻ, có thể hạn chế những yếu tố nguy cơ có thể ảnh hưởng đến thời kỳ mang thai [4].

Từ những vấn đề trên cho thấy bệnh nhiễm T. gondii là một bệnh rất phổ biến và còn chưa được quan tâm đúng mức. Tại Việt Nam, các nghiên cứu về nhiễm T. gondii trong cộng đồng chưa nhiều, đặc biệt khu vực miền Trung và Tây Nguyên cho đến nay rất ít đề tài nghiên cứu nhiễm T. gondii. Để xác định tỷ lệ huyết thanh dương tính T. gondii cũng như một số yếu tố liên quan góp phần vào sự lưu hành của bệnh và đề xuất biện pháp phòng chống, chúng tôi thực hiện đề tài: "Tỷ lệ và một số yếu tố liên quan đến huyết thanh dương tính với Toxoplasma gondii ở phụ nữ tuổi sinh đẻ huyện Krông Bông, tỉnh Đắk Lắk năm 2020" với hai mục tiêu sau:

1. Xác định tỷ lệ huyêt thanh dương tính với Toxoplasma gondii ở phụ nữ tuổi sinh đẻ tại 3 xã (YangReh, Ea Trul và Hòa Sơn) huyện Krông Bông, tỉnh Đắk Lăk.

2. Mô tả một số yếu tố liên quan đến nhiễm Toxoplasma gondii ở phu nữ tuổi sinh đẻ tại điểm nghiên cứu.

\section{II. ĐỐI TƯợNG VÀ PHƯƠNG PHÁP NGHIÊN CỨU}

2.1 Đối tượng nghiên cứu. Phụ nũ̃ trong độ tuổi sinh đẻ từ 16-49 tuổi đang sinh sống trên địa bàn nghiên cứu của huyện Krông Bông, Tỉnh Đắk Lắk.

Tiêu chí chọn mẫu. Đối tượng nghiên cứu được chọn trong danh sách; Được mã số vào danh sách; Được cộng tác viên y tế xã đến mời và đồng ý hợp tác nghiên cứu lấy mẫu máu xét nghiệm và phỏng vấn KAP.

Tiêu chí loại trừ: Những đối tượng từ chối không hợp tác; Không có trong danh sách xã.

Kỹ thuật lấy mẫu:

\section{KẾT QUẢ NGHIÊN CỨU}

3.1 Liên quan giữa tỷ lệ huyêtt thanh dương tính và đặc điểm chung của nhóm nghiên cứu Bảng 3.1 Tỷ lể huyết thanh dương tính theo xã cư trú

\begin{tabular}{|c|c|c|c|c|c|c|c|}
\hline Xã & $\begin{array}{c}\text { Số XN } \\
(+)\end{array}$ & $\begin{array}{c}\text { Tỷ lệ } \\
\%\end{array}$ & $\begin{array}{c}\text { Số XN } \\
(-)\end{array}$ & $\begin{array}{c}\text { Tỷ lề } \\
\%\end{array}$ & $\begin{array}{c}\text { Tân số } \\
\text { (n) }\end{array}$ & $\mathbf{p}$ & $\begin{array}{c}\text { PR } \\
\text { (KTC95\%) }\end{array}$ \\
\hline Yan & 33 & 29,2 & 80 & 70,8 & 113 & & \\
\hline $\mathrm{Ea}$ & 10 & 19,2 & 42 & 80, & 52 &, 1 & $1,73(0,7)$ \\
\hline Hòa Sơn(3) & 10 & 4,3 & 221 & 95,7 & 231 & 0,000 & $, 3), 9,12(4,30-19,34)$ \\
\hline
\end{tabular}

Qua nghiên cứu của 3 xã Yang Reh, Ea Trul và xã Hòa Sơn cho thấy tỷ lệ nhiềm T. gondii giữa xã Yang Reh chiếm $29,2 \%$ và xã Ea Trul chiếm 19,2\% không có sự khác biệt, với $P R=1,73$ và $p>0,05$; riêng xã Hòa Sơn chiếm 4,3\% so với xã Yang Reh chiếm 29,2\% có sự khác biệt, $P R=9,17$ và $p<0,05$.
Khung mẫu: Danh sách phụ nữ trong độ tuổi sinh đẻ tại 3 xã. Với cõ̃ mẫu điều tra là 396 người

2.2 Thời gian nghiên cứu. Từ tháng 01 năm 2020 đến tháng 07 năm 2020

2.3 Cỡ mẫu. Đây là nghiên cứu ước lượng một tỷ lệ trong một dân số nên chúng tôi áp dụng công thức tính cõ̃ mẫu [2]:

$$
n=Z_{1-\alpha / 2}^{2} \frac{p(1-p)}{d^{2}}
$$

Trong nghiên cứu này chúng tôi chọn:

$\mathrm{d}=0,05$

$p=0,5$ (Chọn $p=0,5$ để có cõ mẫu tối thiểu cần thiết lớn nhất vì:

+ Chưa có nghiên cứu nào trước đó tại địa phương;

+ Các nghiên cứu khác trước đó trền phụ nữ khám thai tại bệnh viện;

+ Một số nghiên cứu cộng đồng khác chưa có sự định hướng về phụ nữ trong độ tuổi sinh đẻ.)

$Z_{(1-a / 2)}=1$, 96 (với $\alpha=0,05$, độ tin cậy $95 \%$ )

Vậy cỡ mẫu sẽ là: $\mathrm{n} \approx 384$ cho điểm nghiên nghiên cứu này chúng tôi chọn cỡ mẫu là 396 người).

2.4 Phương pháp nghiên cứu. Nghiên cứu tỷ lệ nhiễm Toxoplasma gondii bằng kỹ thuật xét nghiệm huyết thanh chẩn đoán ELISA tìm kháng thể IgG kháng với Toxoplasma gondii trong máu của đối tượng nghiên cứu.

Nghiên cứu một số yếu tố liên quan về kiến thức, thái độ, thực hành như: vệ sinh ăn uống, rửa tay trước ăn, tiếp xúc mèo, nuôi mèo, ăn rau sống... bằng kỹ thuật điều tra phỏng vấn theo bộ câu hỏi KAP mặt đối mă̆t.

Thu nhận và chuẩn bị mẫu:

- Thu nhận mấu máu toàn phần và tách rời huyết thanh tại cộng đồng nơi điều tra

- Mẫu có thể được giữ lanh ở 2-8 đô C tới 7 ngày hoặc giữ đông tới 6 tháng.

- Tất cả mẫu bệnh phẩm được thực hiện xét nghiệm tại Khoa Xét Nghiệm, Bệnh viện Đa Khoa Vùng Tây Nguyên, Thành phố Buôn Mê Thuột, Tỉnh Đắk Lắk. cứu (Cộng thêm 3\% những người bỏ cuộc, trong 
Bảng 3.2 Tỷ lệ tăng BCAT trên số trường hợp huyêt thanh dương tính

\begin{tabular}{|c|c|c|c|c|c|c|c|}
\hline $\begin{array}{c}\text { Tỷ lệ \% BCAT } \\
\text { trong máu }\end{array}$ & $\begin{array}{c}\text { Số XN } \\
(+)\end{array}$ & $\begin{array}{c}\text { Tỷ lệ } \\
\text { \% }\end{array}$ & $\begin{array}{c}\text { Số XN } \\
(-)\end{array}$ & $\begin{array}{c}\text { Tỷ lệ } \\
\text { \% }\end{array}$ & $\begin{array}{c}\text { Tân sốn } \\
(\mathbf{n})\end{array}$ & p & PR \\
\hline Tăng & 14 & 21,9 & 50 & 78,1 & 64 & \multirow{2}{*}{0,029} & 2,10 \\
\hline Bình Thường & 39 & 11,7 & 293 & 88,3 & 332 & & $(1,07-4,15)$ \\
\hline
\end{tabular}

Qua xét nghiệm máu của 396 đối tượng tham gia nghiên cứu, cho thấy chỉ số tăng BCAT rất có giá trị chẩn đoán, sự tăng bạch cầu ái toan tăng gấp 2,10 lần trên số trường hợp huyết thanh tính, với $p<0,05$.

Bảng 3.3 Tỷ lệ huyêt thanh dương tính theo nghề nghiệp

\begin{tabular}{|c|c|c|c|c|c|c|c|}
\hline Nghề nghiệp & $\begin{array}{c}\text { Số XN } \\
(+)\end{array}$ & $\begin{array}{c}\text { Tỷ lề } \\
\%\end{array}$ & $\begin{array}{c}\text { Số XN } \\
(-)\end{array}$ & $\begin{array}{c}\text { Tỷ lệ } \\
\%\end{array}$ & $\begin{array}{c}\text { Tân số } \\
\text { (n) }\end{array}$ & $\mathbf{p}$ & $\begin{array}{c}\text { PR } \\
\text { (KTC95\%) }\end{array}$ \\
\hline (1) & 33 & 11,7 & 250 & 88,3 & 283 & \multirow{2}{*}{0,004} & $(1,2) ;$ \\
\hline Buô & 11 & 28,2 & 28 & 71,8 & 39 & & $0,34(0,15-0,74)$ \\
\hline (3) & 2 & 8.0 & 23 & 92.0 & 25 & 0,580 & $(1,3) ; 1,52(0,34-6,73)$ \\
\hline Khác (4) & 7 & 14,3 & 42 & 85,7 & 49 & 0,602 & $(1,4) ; 0,79(0,33-1,91)$ \\
\hline
\end{tabular}

Tỷ lệ nhiễm T. gondii giữa nhóm làm nông và nhóm buôn bán có sự khác biệt, với $p<0,05$. Giá tr $\mathrm{PR}<1$ (khoảng tin cậy $95 \%$ không chứa 1$)$, điều này nói lên rằng, làm nông có nguy cớ nhiếm chì bằng 0,34 hay nói cách khác nhóm buôn bán nguy cơ nhiễm T. gondii gấp 2,98 lần so với nhóm làm nông. Ớ nhóm làm nông và các nhóm còn lại không có sự khác biệt, với p>0,05.

Bảng 3.4 Tỷ lệ huyêt thanh dương tính theo dân tộc

\begin{tabular}{|c|c|c|c|c|c|c|c|}
\hline Dân tộc & $\begin{array}{c}\text { Số XN } \\
(+)\end{array}$ & $\begin{array}{l}\text { Tỷ lề } \\
\%\end{array}$ & $\begin{array}{c}\text { Số XN } \\
(-)\end{array}$ & $\begin{array}{c}\text { Tỷ lệ } \\
\%\end{array}$ & $\begin{array}{c}\text { Tân số } \\
\text { (n) }\end{array}$ & $\mathbf{p}$ & $\begin{array}{c}\text { PR } \\
\text { (KTC95\%) }\end{array}$ \\
\hline Dân tộc kinh (1) & 35 & 11,4 & 271 & 88,6 & 306 & \multirow{2}{*}{0,035} & \multirow{2}{*}{$\begin{array}{c}0,51 \\
(0,27-0,96)\end{array}$} \\
\hline Dân tộc khác (2) & 18 & 20,0 & 72 & 80,0 & 90 & & \\
\hline
\end{tabular}

Qua xét nghiệm máu của 396 đối tượng tham gia nghiên cứu, cho thây tỷ lệ nhiếm theo thành phần dân tộc có ý nghĩa thống kê, $p<0,05$.

3.2 Liên quan giữa kiến thức, thái độ, thực hành và tình trạng nhiễm T. gondii

Bảng 3.5 Liên quan giữa nguồn nước sử dụng và tình trạng nhiếm T. gondii

\begin{tabular}{|c|c|c|c|c|c|c|c|}
\hline $\begin{array}{l}\text { Nguồn nước } \\
\text { sử dụng }\end{array}$ & $\begin{array}{l}\text { Số XN } \\
(+)\end{array}$ & $\begin{array}{c}\text { Tỷ lệ } \\
\%\end{array}$ & $\begin{array}{c}\text { Số XN } \\
(-)\end{array}$ & $\begin{array}{l}\text { Tỷ lệ } \\
\%\end{array}$ & $\begin{array}{c}\text { Tân số } \\
\text { (n) }\end{array}$ & p & $\begin{array}{c}\text { PR } \\
\text { (KTC95\%) }\end{array}$ \\
\hline Nước máy(1) & 4 & 13,8 & 25 & 86,2 & 29 & \multirow{2}{*}{0,844} & \\
\hline Nước giếng(2) & 45 & 12,5 & 314 & 87,5 & 359 & & $1.12(0,37-3.36)$ \\
\hline Khác (3) & 4 & 50,0 & 4 & 50,0 & 8 & 0,027 & $(1,3) ; 0,16(0,03-0.91)$ \\
\hline
\end{tabular}

Tỷ lê nhiễm giữa nhóm sử dụng nguồn nước máy chiếm $13,8 \%$ so với nhóm sử dunng nước giếng $12,5 \%$ không có sự khác biệt, p $>0,05$. Ở nhóm sử dụng nguồn nước máy chiếm $13,8 \%$ so với nhóm sử dung nguî̀n nước khác $50,0 \%$, có sự khác biệt, với $\mathrm{p}<0,05$. Giá trị $P R<1$ (khoảng tin cây $95 \%$ của $\mathrm{PR}$ không chứa 1 ), điều này nói lên rằng sử dụng nước máy là yếu tố bảo vệ. Tóm lại sử dụng nước máy có nguy cơ nhiễm chỉ bằng 0,16 hay nói cách khác sử dụng nước khác (nước mưa, ao hồ, sông suối...) nguy cơ nhiễm T. gondii gấp 3,62 lần so với sử dụng nước máy.

Bảng 3.6 Liên quan giứa nuôi mèo, tiếp xúc mèo và tình trạng nhiếm T. gondii

\begin{tabular}{|c|c|c|c|c|c|c|c|c|}
\hline \multicolumn{2}{|c|}{ Tình trạng } & $\begin{array}{c}\text { Số XN } \\
(+)\end{array}$ & $\begin{array}{c}\text { Tỷ lệ } \\
\%\end{array}$ & $\begin{array}{c}\text { Số XN } \\
(-)\end{array}$ & Tỷ lệ \% & $\begin{array}{c}\text { Tần số } \\
\text { (n) }\end{array}$ & \multirow{3}{*}{$\begin{array}{c}\mathbf{p} \\
0,043\end{array}$} & \multirow{3}{*}{$\begin{array}{c}\text { PR } \\
\text { (KTC95\%) } \\
1,18 \\
(1,01-3,25)\end{array}$} \\
\hline & Có & 26 & 17,9 & 119 & 82,1 & 145 & & \\
\hline NuOI n & Khôr & 27 & 10,8 & 224 & 89,2 & 251 & & \\
\hline Tiếp & C & 32 & 33,7 & 63 & 66,3 & 95 & & 6.77 \\
\hline mèo & Không & 21 & 7,0 & 280 & 93,0 & 301 & 0,000 & $(3.66-12.5)$ \\
\hline
\end{tabular}

Ơ nhóm nuôi mèo $(17,9 \%)$ có nguy cơ nhiếm T. gondii gấp 1,18 lần so với nhóm không nuôi mèo $(10,8 \%)$. ̛̛̉ nhóm tiếp xúc mèo sẽ có nguy cơ nhiễm T. gondii gâp 6,77 lần so với nhóm không có tiếp xúc.

Bảng 3.7 Liên quan giứa nhiếm T. gondii và tình trạng sây thai, thai lưu

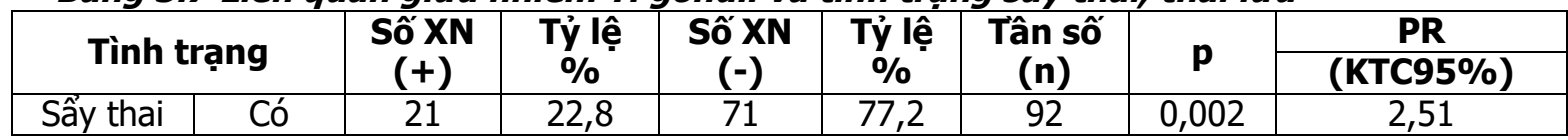




\begin{tabular}{|c|c|c|c|c|c|c|c|c|}
\hline & Không & 32 & 10,5 & 272 & 89,5 & 304 & & $(1,37-4,62)$ \\
\hline \multirow{2}{*}{ Thai lưu } & Có & 18 & 31,6 & 39 & 68,4 & 57 & \multirow{2}{*}{0,000} & 4,01 \\
\cline { 2 - 9 } & Không & 35 & 10,3 & 304 & 89,7 & 339 & \multirow{2}{*}{$(2,07-7,75)$} \\
\hline
\end{tabular}

Qua nghiên cứu của 396 đối tượng cho thấy tỉ lệ nhiếm T. gondii giữa nhóm có sấy thai gấp 2,51 lần với nhóm không sẩy thai có sự khác biệt có ý nghĩa thống kê, với $p<0,05$.

Tỷ lệ nhiếm T. gondii so với nhóm thai lưu có nguy cơ gấp 4,01 lần so với nhóm không có thai lưu, sự khác biệt này có ý nghĩa thống kê, với $p<0,05$.

\section{BÀN LUẬN}

4.1. Tỷ lệ huyết thanh dương tính Toxoplasma gondii phụ nữ trong độ tuổi sinh đẻ tại điểm nghiên cứu.

Tỷ lệ huyết thanh dương tính theo xã cư trú. Ở tất cả các dân cư 3 xã đều có người nhiễm, mặc dù Xã Yang Reh và Xã Ea Trul không có sự khác biệt, tuy nhiên Xã Hòa Sơn so với Xã Yang Reh có sự khác biệt. Tỷ lệ nhiễm ở xã Yang Reh cao gấp 9,12 lần Xã Hòa Sơn (bảng 3.1). Môi trường sống, thói quen sinh hoạt, điều kiện kinh tế, vệ sinh ăn uống, ăn uống những thực phẩm có nguy cơ lây nhiễm, dân số mèo cao, tiếp xúc mèo ở mỗi khu vực dân cư khác nhau, tạo ra sự khác biệt về tỷ lệ nhiễm T. gondii.

Nghiền cứu của chúng tôi cũng giống với nghiên cứu tỷ lệ nhiễm $T$. gondii trên phụ nữ khám thai khám tại Bệnh viện Đa khoa Lâm Đồng năm 2013 của tác giả Đoàn Hoàng Anh, có sự khác biệt giữa các khu vực dân cư [1].

Những kêt quả này phù hợp với nghiên cứu của chúng tôi, sự khác biệt có ý nghĩa ở các khu vực dân cư. Đó là một trong những nguyên nhân dấn tới tỷ lệ nhiễm khác biệt đặc trưng theo khu vực. Sự khác biệt này giữa các địa điểm có thể do tình trạng kinh tế xã hội của những người tham gia, điều này có thể ảnh hưởng đến thực hành vệ sinh và khả năng ăn phải noãn bào từ nước, cầy trồng, sản phẩm động vật và sữa chưa tiệt trùng bị nhiễm bẩn từ noãn bào do mèo đổ ra và đất bị ô nhiê̂m.

Tỷ lệ bạch câu ái toan trong trường hợp huyết thanh dương tính. Tỷ lệ tăng BCAT ở đối tượng nghiên cứu của chúng tôi là 16,2\%. Kết quả nghiên cứu cho thấy các đối tượng tăng BCAT trong máu ngoại vi có nguy cơ huyết thanh dương tính với T. gondii, sự gia tăng bạch cầu gấp 2,10 lần so với những trường hợp không tăng bạch cầu, rất có giá trị chẩn đoán. Tỷ lệ tăng BCAT trên số trường hợp huyết thanh dương tính là 21,9\% (bảng 3.2).

Tỷ lệ huyêt thanh dương tính theo nghề nghiệp. Kết quả nghiên cứu (bảng 3.3) cho thấy sự phân công lao động trong xã hội, tính chất cổng việc, đặc điểm ngành nghề, những việc làm có điều kiện tiếp xúc với một số yếu tố thuận lợi cho lây nhiễm T. gondii, cũng như kiến thức hiểu biết, tác hại, biện pháp phòng chống bệnh phải dựa trên kiến thức hiểu biết, tác hại và cách phòng chống.

Tỷ lệ huyết thanh dương tính theo dân tộc. Với mục đích tìm những yếu tố liên quan mang bản sắc dân tộc, nghiên cứu của chúng tôi đã quan tâm tới thành phần dân tộc, cũng như tới tập tục trong tôn giáo. Tuy nhiên về yếu tố thành phần dân tộc (Bảng 3.4), tỷ lệ nhiễm ở các dân tộc khác có cao hơn so với dân tộc Kinh, sự khác biệt có ý nghĩa thống kê; về yếu tố tôn giáo, kểt quả nghiên cứu có nhiễm T.gondii thuộc các nhóm tôn giáo khác nhau có sự khác biệt, có ý nghĩa thống kê với $p<0,05$. Mặc dù trong nghiên cứu của chúng tôi dân tộc kinh chiếm tỳ lệ khá cao $77,3 \%$, dân tộc khác chiếm $22,7 \%$, tỷ lệ nhiếm T. gondii trong nhóm dân tộc khác nguy cơ nhiễm cao gấp 1,75 lần so với nhóm dân tộc người kinh, có sự khác biệt về tỷ lệ nhiếm giữa 2 nhóm dân tộc, $p<0,05$. Kết quả của chúng tôi thể hiện có sự khác nhau giữa các dân tộc, giống với một nghiên cứu tại Trung Quốc vào năm 2016, trong số những nhóm này, dân tộc Mông Cổ có tỷ lệ huyết thanh $\mathrm{T}$. gondii cao nhất $(20,74 \%, 45 / 217)$, tiếp theo là dân tộc Hàn Quốc $(16,54 \%, 86 / 520)$, dân tộc Mãn Châuu (13,86\%, 42/303) và dân tộc Hán $(11,35 \%, 98 / 802)$.

4.2. Một số yếu tố liên quan nhiếm Toxoplasma gondii tại điểm nghiên cứu.

Liên quan giữa nguồn nước sử dụng và tình trạng nhiếm T. Gondii. Theo bảng 3.5, phân tích mối liên hệ giữa nguồn nước sử dụng và huyết thanh dương tính với $T$. gondii cho thấy sự khác biệt rất lớn. Tỷ lệ uống nước sạch bao gồm nước máy, nước giếng chiếm lần lượt 7,3\%, $90,7 \%$, trong khi đó việc sử dụng nguồn nước không đảm bảo vệ sinh chiếm tỷ lệ 2,0\%. Điều này nói lên rằng yếu tố nguồn nước sử dụng sạch là yếu tố bảo vệ. Việc sử dung nguồn nước không đảm bảo có nguy cơ nhiểm gấp 3.62 lần so với nhóm sử dụng nguồn nước vệ sinh (nước máy, nước giếng). Kết quả của chúng tôi cũng giống một nghiên cứu trên 760 đối tượng phụ nữ khám thai tại Bệnh bệnh viện Songklanagarind, miền Nam Thái Lan, cho thấy mối liên quan đáng 
kể giữa T. gondii nhiễm trùng và sử dụng nước chưa qua xử lý.

Sự khác biệt này giữa các địa điểm có thể do tình trạng kinh tế xã hội của những người tham gia, điều này có thể ảnh hưởng đến thực hành vệ sinh và khả năng ăn phải noãn bào từ nước, cầy trồng, sản phẩm động vật và sữa chưa tiệt trùng bi nhiếm bẩn từ noãn bào do mèo đổ ra và đất bị ô nhiễm. Phụ nữ trong độ tuổi sinh đẻ, lao động và tiếp xúc với nước không sạch từ nhiều nguồn khác nhau có nguy cơ nhiễm Toxoplasma cao hơn. Do đó, cần phải giáo dục sức khỏe và nâng cao nhận thức về nguy cơ mắc bệnh KST T. gondii để giảm thiểu tác động của bệnh nhiễm KST này ở phụ nữ trong độ tuổi sinh đẻ cũng như người dân nói chung.

Liên quan giữa nuôi mèo và tình trạng nhiễm T. Gondii. Tỷ lệ nhiễm ở nhóm nuôi mèo và không nuôi mèo $17,9 \%$ và $10,8 \%$ (bảng 3.6). Có sự khác biệt về tỷ lệ nhiễm và nuôi mèo, với $\mathrm{PR}=1,18, \mathrm{p}<0,05$, mắc dù số lượng người nuôi mèo chiếm $36,6 \%$ ít hơn so với nhóm không nuôi mèo $63,4 \%$. Kết quả của chúng tôi giống với tác giả Đoàn Hoàng Anh [1], nguy cơ nhiễm T. gondii ở nhóm nuôi mèo cao gấp 2,3 lần so với nhóm không nuôi mèo; so với nghiên cứu tại Nhật năm 2011 của Makiko Sakikawa trên phụ nữ khám thai, kết quả của chúng tôi ngược lại, viêc nuôi mèo lại không có liên quan đáng kể đển nguy cơ lây nhiễm Toxoplasma (KTC 95\%, $0,680-1,001 ; p>0,05)$. Mèo là thú nuôi tại Nhật, được nuôi chăm sóc rất chu đáo, mèo có những hộp cát để thải phân ra ngoài. Do đó, những người nuôi mèo tại Nhật đã hạn chế tiếp xúc với nang noãn thải ra từ phân mèo.

Nguy cơ nhiễm trùng $\mathrm{T}$. gondii ở người bắt nguồn từ việc tiếp xúc với phân của một con mèo đang rụng trứng. Mèo thường rụng trứng chỉ trong một vài tuần trong suốt cuộc đời của chúng. Những con mèo được nuôi trong nhà, không săn bắt và không được cho ăn thit sống sẽ không có khả năng bị nhiễm $T$. gondii và do đó gây ra ít rủi ro cho con người. Ngoài ra, mèo hàng xóm hoặc mèo hoang đi đại tiện trong vườn hoặc hộp cát có thể gây nguy cơ nhiễm trùng T. gondii cao nhất cho một số người, bất kể họ có sở hữu mèo hay không.

Kết quả nghiên cứu của chúng tôi cho thấy nuôi mèo, từng nuôi mèo chiếm $36,6 \%$, tuy nhiên tỷ lệ huyết thanh dương tính trong nhóm nuôi mèo chiếm tỷ lệ 17,9\% so với nhóm không có nuôi mèo $10,8 \%$, có sự khác biệt tỷ lệ nhiễm giữa hai nhóm, sự khác biêt này có ý nghĩa thống kê. Mối liên quan này cho thấy kết quả nghiên cứu của chúng tôi phù hợp với những kết quả khác như trong y văn. Tại các vùng nông thôn hay như tại 3 xã nghiên cứu của chúng tôi, việc nuôi mèo trong nhà nhưng không có đảm bảo tình trạng vệ sinh khi mèo thải phân ra ngoài, có thể góp phần gia tăng những nguy cơ tiếp xúc với nang noãn. Mèo không có nơi để đại tiện mà phóng uế thẳng ra môi trường bển ngoài, xung quanh nhà, đặc biệt hơn là mèo có rất thích được âu yếm với người, vuốt ve, điều này dễ gia tăng nguy cơ nhiểm do tiếp xúc với mèo khi nuôi mèo.

\section{Liên quan giữa tiếp xúc với mèo và tình} trạng nhiễm T. Gondii. Tiếp xúc với mèo không có nghĩa là phải nuôi mèo, chúng tôi muốn phân biệt rõ về nuôi mèo và có tiếp xúc mèo là 2 yếu tố nguy cơ khác nhau. Tiếp xúc mèo có nghĩa là tiếp xúc ở khắp mọi nơi, chứ không phải mặc định là ở nhà mình. Đối tượng không nuôi mèo nhưng hàng xóm hoặc ở nhà khác có nuôi mèo, khi đối tượng có sở thích bế ẵm chơi nô đùa với mèo, trứng nang có thể ở phân mèo bám dính lên chân, lông... rồi dính vào tay chân, mặt mũi, quần áo... môi trường xung quanh người tiếp xúc và có thể trực tiếp hay gián tiếp bị nhiễm qua ăn uống. Trong nghiên cứu của chúng tôi (bảng 3.6), nhóm tiếp xúc mèo có tỷ lệ nhiểm khá cao 33,7\% so với nhóm không tiếp mèo $7,0 \%$. Với $P R=6,77 \%, p<0,05$ có ý nghĩa thống kê trong nghiên cứu của chúng tôi. Nhóm tiếp xúc mèo có nguy cơ nhiễm gấp 6,77 lần so với nhóm không có tiếp xúc.

Nguy cơ nhiễm $\mathrm{T}$. gondii ở người bắt nguồn từ việc tiếp xúc với phân của một con mèo đang rụng trứng. Mèo thường rụng trứng chỉ trong vài tuần trong suốt cuộc đời của chúng. Những con mèo được nuôi trong nhà, không săn bắt và không được cho ăn thịt sống sẽ không có khả năng bị nhiễm $\mathrm{T}$. gondii và do đó ít gây rủi ro cho con người. Ngoài ra, những con mèo hoang hoặc khu phố đi vê sinh trong vườn có thể gây ra nguy cơ nhiễm T. gondii cao nhất cho một số người, bất kể họ có nuôi mèo hay không.

Mèo nhà và mèo hoang đã được coi là nguî̀n chính của noãn bào Toxoplasma, mặc dù yếu tố nguy cơ chính là mối quan hệ giữa quần thể mèo và kích thước khu vực chúng đi vệ sinh. Số lượng mèo nông thôn thường cao hơn mèo thành thị, nhưng mèo thành thị phóng uế ở những khu vực hạn chế: bãi cát bên trong nhà ở, khu vườn nhỏ và xung quanh nhà. Ở nhứng khu vực này, nồng độ tế bào trứng của Toxoplasma có thể rất cao, do đó nguy cơ lây nhiễm cũng có thể tăng lên ở người, trong khi mèo nông thôn có khu vực rộng 
để đi vệ sinh và nồng độ tế bào trứng ở những khu vực này thấp hơn so với trường hợp trước đó, là nhiễm nguy cơ thấp ở người dân nông thôn.

Liên quan giữa nhiễm $T$. gondii và tình trạng sẩy thai, thai lưu. Phần lớn trong nghiên cứu của chúng tôi phụ độ tuổi sinh đẻ chiếm tỷ lệ khá cao, thậm chí sinh con trên từ 12 lần chiếm $59,3 \%$, từ 3 lần trở lên chiếm $30,6 \%$, trong khi nhóm chưa sinh chiếm $10,1 \%$. Như vậy tỷ lệ nhiếm T. gondii chiếm tỳ lệ cao 13,4\% trong cộng đồng chủ yếu là ở những phụ nữ trong sinh đẻ. Do đó việc theo dõi sẩy thai, thai chết lưu trong cộng cộng đồng rất đáng được quan tâm, vì nhiếm T. gondii ảnh hưởng có thể gây hậu quả cho thai nhi, những thể bệnh Toxoplasma bẩm sinh, tổng thương hệ thần kinh trung ương hay như ở những thể bệnh nặng có thể gây viêm màng não, tổn thương ở phổi, tim...[6], [7].

Kết quả nghiên cứu tại bảng 3.29 cho thãy, tỷ lệ sẩy thai, tiên sử sẩy thai chiếm $23,2 \%$, đây là yếu tố hậu quả để khảo sát khi bị nhiễm. Trong nghiên cứu cho thây tỷ lệ sẩy thai ở cả hai nhóm có nhiễm và không nhiễm chênh lệch nhau về tỷ lệ nhiễm (22,8\% và $10,5 \%)$, mối liên quan giữa nhiễm $\mathrm{T}$. gondii và tình trạng sẩy thai có ý nghĩa thống kê. Sự phát hiện huyết thanh Toxoplasma được báo cáo ở phu nữ trong đô tuổi sinh đẻ trong nghiên cứu của chúng tôi có thể có tác động có hại cho thai nhi do nguy cơ nhiễm trùng bẩm sinh. Nhiễm trùng bẩm sinh là mô̂t phần quan trong của gánh nặng bênh tật trong các trường hợp nhiễm Toxoplasma ở người.

\section{KẾT LUÂ̂N}

Qua nghiên cứu cắt ngang 396 đối tượng phụ nữ trong độ tuổi sinh đẻ tại 3 xã Yang Reh, xã Ea Trul, xã Hòa Sơn huyện Krông Bông tỉnh Đắk Lắk từ tháng 01 đến tháng 07 năm 2020, chúng tôi đưa ra một số kết luận như sau:

Tỷ lệ huyết thanh dương tính Toxoplasma gondii bằng xét nghiệm IgG ELISA tại 3 điểm nghiên cứu là $13,4 \%$ (trong đó $29,2 \%$ ở Yang Reh, $19,2 \%$ ở Ea Trul và 4,3\% ở Hòa Sơn).

Một số yếu tố liên quan nhiễm Toxoplasma gondii tại điểm nghiên cứu

+ Nhóm người dân tộc có nguy cơ nhiễm cao. Huyết thanh dương tính với Toxoplasma gondii ở nhóm người dân tộc cao gấp 1,75 lần người kinh.

+ Có mối liên hệ giữa khu vực dân cư và tình trạng nhiễm. Huyết thanh dương tính với Toxoplasma gondii tại Xã Rang Reh cao gấp 9,12 lần so với Xã Hòa Sớn.
+ Người buôn bán có nguy cơ nhiễm Toxoplasma gondii cao gấp 2,98 lần so với những người làm nông.

+ Những người sử dụng nguồn nước không đảm bảo vệ sinh có nguy cơ nhiễm Toxoplasma gondii cao gấp 3,62 lần so với nhóm sử dụng nguồn nước hợp vệ sinh.

+ Người nuôi mèo có nguy cơ nhiễm Toxoplasma gondii cao gấp 1,18 lần so với những người không nuôi mèo.

+ Những người tiếp xúc mèo có nguy cơ nhiễm Toxoplasma gondii cao gấp 6,77 lần so với những người không tiếp xúc mèo.

+ Những đối tượng phụ nữ trong độ tuổi sinh đẻ có huyết thanh dương tính cao gấp 2,51 lần; Nguy cơ thai lưu trên những đối tượng phụ nữ trong độ tuổi sinh đẻ có huyết thanh dương tính cao gấp 4,01 lần.

\section{TÀI LIÊU THAM KHẢO}

1. Đoà̀n Hoàng Anh (2013), Tỷ lệ nhiễm Toxoplasma gondii trên phụ nứ có thai tới khám thai tại Bệnh viện Đa khoa Tỉnh Lâm Đồng, Luận văn Thạc sĩ Y học, chuyên ngành ký sinh trùng côn trùng y học, Đại học Tây Nguyên.

2. Đinh Thị Bích Lân, Huỳnh Văn Chương (2009), Viện TNMT \& CNSH Đại học Huế - Kiểm tra kháng thể kháng Toxoplasma gondii trong huyết thanh người và gia súc tại Thừa Thiên Huế Tap chí khoa học, Đai hoc Huế, số 55.

3. A. F. Fatoohi, G. j. N. Cozon, P. Gonzalo, M. Mayencon, T. Greenland, S. Picot \& F. Peyron E.A (2004), Heterogeneity in cellular and humoral immune responses against Toxoplasma gondii antigen in humans, Clin Exp Immunol, 136: p. 535-541.

4. A. Molan, K. Nosaka, M.Hunter, W. Wang (2019), Global status of toxoplasma gondii infection: Systematic review and prevalence snapshots, Tropical biomedicine, 36(4): p. 898-925.

5. Elvis Chongsi Wam, Leonard Fonkeng Sama, Innocent Mbulli Ali, Walter Akoh Ebile, LucyAgyingi Aghangu, and Christopher Bonglavnyuy Tume (2016) - Seroprevalence of Toxoplasma gondii IgG and IgM antibodies and associated risk factors in women of child-bearing age in Njinikom, NW Cameroon, BMC res Note, 9:406.

6. Hendrik Wilking, Michael Thamm, Klaus Stark, Toni Aebischer and Frank Seeber (2016), Prevalence, incidence estimations, and risk factors of Toxoplasma gondii infection in Germany: a representative, cross-sectional, serological study, Scientific reports, 6:22551.

7. J. FLEGR - Division of Biology, Falcuty of Science, Charles University in Prague, Prague, Klecany 250 67, Czech Republic (2017), Predictors of Toxoplasma gondii infection in Czech and Slovak population: the possible role of cat-related injuries and risky sexual behavior in the parasite transmission, Epidemiol. Infect, 145, p. $1351-1362$. 